\title{
РАДИАЦИОННО-ИНДУЦИРОВАННЫЕ ПРЕВРАЩЕНИЯ ТРИПТОФАНА И ЕГО ПРОИЗВОДНЫХ В ОКСИГЕНИРОВАННОМ ЭТАНОЛЕ
}

\author{
Бринкевич С.Д., Кузьмук Д.А., Свердлов Р.Л., Шадыро О.И. \\ Белорусский государственный университет, Минск, Беларусь
}

Триптамин, серотонин, мелатонин, мексамин и другие производные триптофана обладают выраженными радиопротекторными, антиоксидантными и нейропротекторными свойствами. Молекулярные механизмы, лежащие в основе их физиологической активности, достаточно разнообразны и являются предметом интенсивного изучения. Радиопротекторные и антиоксидантные свойства производных триптофана могут быть обусловлены их взаимодействием с углерод- и кислородцентрированными радикалами [1]. В настоящей работе методом стационарного радиолиза изучено взаимодействие триптофана, триптамина и 3индолпропионовой кислоты с пероксильными радикалами, образующимися при радиолизе этанола, насыщенного кислородом.

Показано, что 3-индолпропионовая кислота проявляет низкую реакционную способность по отношению к пероксильным радикалам, о чем свидетельствуют незначительные изменения величин радиационнохимических выходов продуктов радиолиза этанола, насыщенного кислородом, при введении тестируемого вещества. При этом триптамин и, в меньшей степени, триптофан, обладающие незамещенной аминогруппой, ингибируют радиационно-индуцированное окисление этанола. Поэтому антиоксидантные свойства триптамина и триптофана могут быть связаны с их способностью восстанавливать кислородцентрированные радикалы за счёт переноса электрона с неподелённой пары аминогруппы. Невысокие радиационно-химические выходы разложения триптамина и триптофана указывают на возможность восстановления катион-радикалов добавок до исходных веществ, например, в реакции с супероксид анионрадикалами или гидропероксильными радикалами. Выявленные закономерности гомолитических реакций с участием триптофана и его производных проливают свет на механизмы формирования антиоксидантной и радиопротекторной активности исследуемых веществ и могут быть полезны для разработки новых регуляторов свободнорадикальных процессов in vivo с полезными фармакологическими свойствами.

Библиографические ссылки:

1. Sverdlov R.L., Brinkevich S.D., Shadyro O.I. // Free radical research. 2014. V. 48. №. 10. P. 1200. 